\title{
Kepemimpinan Ustadz Iwan Hermawan dalam Mengembangkan Pondok Pesantren Salafiyah Al-Mu'awanah
}

\author{
Siti Muspiroh*, A. Bachrun Rifai, \& Herman \\ Jurusan Manajemen Dakwah, Fakultas Dakwah dan Komunikasi, \\ UIN Sunan Gunung Djati, Bandung \\ *Email: sitimusfirob@gmail.com
}

\begin{abstract}
ABSTRAK
Pondok Pesantren Salafiyah Al-Mu'awanah merupakan lembaga pendidikan Islam yang mampu bertahan di tengah-tengah perkembangan zaman. Lembaga ini telah melewati berbagai macam ujian serta perkembangan diberbagai bidang. Dibalik berkembang dan majunya suatu lembaga tentu dibelakangnya ada seorang pemimpin yang mampu mengendalikan serta menggerakan roda organisasi sehingga pada akhirnya tujuan yang telah dirumuskan telah tercapai. Penelitian ini bertujuan untuk mengetahui Tipe Kepemimpinan Ustadz Iwan Hermawan dalam Mengembangkan Pondok Pesantren Salafiyah Al-Mu'awanah, cara Pengambilan Keputusan dalam suatu permasalahan, dan bagaimana Human Relation (Hubungan antar manusia) Santri dengan Ustadz Iwan Hermawan dalam Mengembangkan Pondok Pesantren. Metode yang digunakan dalam penelitian ini adalah metode deskriptif, hasil penelitian ini adalah Tipe kepemimpinan Ustadz Iwan Hermawan merupakan tipe demokratis dan kharismatik, Ustadz Iwan Hermawan memberikan kesempatan untuk seluruh santri agar dapat bekerjasama mengembangkan dan memajukan Pondok Pesantren, beliau memiliki krakter yang kuat, kepribadian yang teguh toleransi yang tinggi, dan memiliki kewibawaan, pengambilan Keputusan ustadz dalam suatu permasalahan selalu mengedepankan asas musyawarah mufakat, memberikan kesempatan kepada santri untuk berpendapat, menerima kritik saran dan masukan dari siapapun untuk kebaikan dan kemajuan Pondok Pesantren.
\end{abstract}

Kata Kunci: Kepemimpinan; Mengembangkan; Pondok Pesantren;

\section{ABSTRACT}

Pondok Pesantren Salafiyah Al-Mu'awanah is an Islamic educational institution that can survive in the midst of the times. This institution has passed various tests and developments in various fields. Behind the development and advance of an institution certainly behind him there is a leader who is able to control and move the wheel of the organization so that ultimately the objectives that have been formulated has been achieved. This study aims to determine the Type of Leadership Ustad₹. Iwan Hermawan in Developing Pondok Pesantren Salafiyah AlMu'awanah, how to Make Decision in a problem, and how Human Relation Relations between humans) Santri with Ustadz. Iwan Hermawan in Developing Pondok Pesantren. The 
Kepemimpinan Ustadz Iwan Hermawan dalam Mengembangkan ...

method used in this research is descriptive method, the result of this research is Ustady Iwan Hermawan's type of leadership is a democratic and charismatic type, Ustadz. Iwan Hermawan provides opportunity for all students to work together to develop and advance Pondok. Pesantren, he has strong krakter, high tolerance, and have the authority, decision-making ustadz in a matter always put forward the principle of consensus mufakat, giving opportunity to students to argue, accept criticism suggestions and input from anyone for the good and progress of Pondoke Pesantren.

Keywords: Leadership; Developing; Pondok Pesantren;

\section{PENDAHULUAN}

Manusia adalah mahluk sosial yang tidak melepaskan diri dari ketergantungan terhadap orang lain, tugasnya manusia harus hidup bermasyarakat. Karena kodratnya saling membutuhkan satu sama lainnya kelompok sosial ini ada yang besar dan nada yang kecil, ada yang sederhana dan nada yang komplek, dari keharusan bermasyarakat ini mengharuskan pada adanya pimpinan dan kepemimpinan.

Dengan demikian, dengan adanya pemimpin dan kepemimpinan dalam hidup ini, maka logika akademik mengambil kesimpulan bahwa untuk mencapai tujuan mahluk sosial ini, butuh kepada pemimpin dan kepemimpinan, mulai dari persekutuan hidup (kelompok) terkecil sampai dalam kelompok terbesar (organisasi) Pemimpin adalah anggota dari sekelompok yang diberi kedudukan tertentu dan diharapkan dapat bertindak sesuai dengan kedudukannya. Seorang pemimpin adalah juga seorang dalam suatu perkumpulan yang diharapkan menggunakan pengaruhnya dalam mewujudkan dan mencapai tujuan kelompok (Nawawi,2006:123).

Pemimpin adalah anggota dari sekelompok yang diberi kedudukan tertentu dan diharapkan dapat bertindak sesuai dengan kedudukannya. Seorang pemimpin adalah juga seorang dalam suatu perkumpulan yang diharapkan menggunakan pengaruhnya dalam mewujudkan dan mencapai tujuan kelompok.

Sebagaimana sabda Rasulullah SAW diriwayatkan bukhori dan muslim, : "Setiap orang dari kamu adalah pemimpin, dan kamu bertanggung jawab atas kepemimpinan itu". (HR.Bukhari).

Pemimpin yang sukses adalah pemimpin yang kreatif, inovatif, dan berjiwa leadership. Karena dengan hal itu, ia akan mampu mengelola dan mengembangkan lembaga atau organisasinya dalam berbagai aspek. Selain itu juga, dapat mempengaruhi orang lain juga secara konstruktif, dan mampu menunjukan jalan serta tindakan benar yang harus dilakukan secara bersama-sama. Sehingga keberadaan lembaganya mampu merubah pola pikir dan pola kehidupan masyarakat yang menonton (M.Munir, 2006:201).

Kepemimpinan mempunyai kedudukan yang sangat penting di setiap lembaga atau organisasi. Tanpa kepemimpinan yang baik, suatu organisasi tidak dapat mencapai sasaran. Sehingga kepemimpinan menjadi motor utama yang mengerakan dan mengarahkan orang lain untuk mencapai tujuan yang diinginkan. 
Dan hal ini merupakan hakikat dari kepemimpinan terutama kepemimpinan dakwah.

Menurut Malayu S.P Hasibuan (2008:197) kepemimpinan adalah seni seorang pemimpin untuk mempengaruhi bawahan, agar mau bekerjasama dan bekerja secara produktif untuk mencapai tujuan organisasi.

Berdasarkan definisi di atas, maka seseorang pemimpin memiliki peranan yang besar terhadap keberhasilan organisasi, karena kepemimpinan bukan saja memiliki kemampuan teknis dan teoritis, tetapi juga harus mampu berkomunikasi dengan lingkungannya sehingga dapat diterima dan dapat menggerakkan bawahannya kearah pencapaian tujuan dengan kemampuan dan kesadaran sendiri.

Pesantren adalah suatu lembaga pendidikan islam dan keagamaan yang berada di tengah-tengah masyarakat Indonesia. Hubungan antara kiyai, Pesantren dan madrasah adalah lingkaran inti dari masyarakat kaum muslimin di Indonesia, yang telah mimiliki jalinan kait mengkait, begitu pula sejak wahyu yang telah lama. Oleh karena itu, pesantren sering disebut sebagai sub kultur dan bukan counter kultur, pesantren sebagai lembaga pendidikan Islam menyimpan berbagai harapan dan problem sebagai dicatat dalam sejarah dan fenomenafenomena faktual dinamika pesantren (Aripudin, 2012:3)

Pondok Pesantren Salafiyah Al-Mu'awanah merupakan salah satu Pondok Pesantren yang berada di Desa Cibiru Wetan, Kecamatan Cileunyi, Kabupaten Bandung. Bergerak dalam bidang keagamaan, seperti halnya Pesantren-Pesantren pada izin Allah, Ustadz Iwan Hermawan menikah dengan putri satu-satunya pa haji di desa ini.

Berdasarkan Pondok Pesantren Salafiyah Al-Mu'awanah dipimpin oleh K.H. Haidar Badrujzaman, dan saat ini diteruskan perjuangannya oleh Ustadz Iwan Hermawan, Beliau adalah pengasuh Pondok Pesantren sekaligus menantu dari anak satu-satunya K.H. Badrujzaman, beliau dipercaya untuk mengembangkan Pondok Pesantren Salafiah Al-Mu'awanah agar lebih maju dan berkembang. Beliau sangat disegani oleh pengurus pesantren dan para santri, beliau sebagai sentral figure untuk masyarakat pesantren dan sebagai pemimpin yang mengayomi ke arah yang bersifat kepesantrenan. Beliau mengambil sebuah tindakan dengan bermusyawarah, meskipun beliau memiliki kepanjangan tangan beliau langsung terjun menanyakan sesuatu yang bersangkutan, jika itu seudah melampaui batasnya (Ustadz Iwan Hermawan 20 Maret 2018).

Dalam pengembangan Pondok Pesantren yang beralokasi di Kampung Lio Warung Gede, Desa Cibiru Wetan, Kecamatan Cileunyi Kabupaten Bandung. Dengan mengajarkan Al-Qur'an kepada santri yang waktu itu hanya memiliki santri sebanyak tiga santri, itupun hanya pengajian kalong/pulang pergi dan tidak untuk menetap di kobong. Tahun demi tahun perkembangan santripun semakin bertambah dan meningkat, yang asal mulanya tidak memiliki santri menetap, saat ini memiliki santri yang menetap, dan awalnya hanya untuk dikhususkan santri ikhwan, saat ini sudah memiliki santri akhwat (Ustadz Iwan Hermawan 20 Maret 2018). 
Selain dilihat dari perkembangan jumlah santri yang ingin belajar, fasilitas dan sarana yang memadai mengalami perubahan menjadi lebih baik dari sebelumnya, dengan perkembangan Pondok Pesantren Al-Mu'awanah tersebut, tidak terlepas dari Kepemimpinan Ustadz Iwan Hermawan beserta istri dan keluarga besar Al-Mu'awanah, selalu mendukung dan membantu untuk perkembangan Pondok Pesantren tersebut sehingga bisa berkembang sampai saat ini.

Dengan adanya pemaparan di atas dan tinjauan sementara, penulis ingin mengetahui lebih jauh mengenai kepemimpinan beliau dalam mengembangkan Pondok Pesantren. Bedasarkan hal tersebut penulis tertarik untuk melakukan penulisan dengan judul “ Kepemimpinan Ustadz Iwan Hermawan dalam Mengembangkan Pondok Pesantren Salafiyah Al-Mu'awanah (Studi Deskriptif terhadap Kepemimpinan Ustadz. Iwan Hermawan sebagai Pemimpin di Pondok Pesantren Salafiyah Al-Mu'awanah Desa Cibiru Wetan Kecamatan Cileunyi Kabupaten Bandung).

Kegunaan penelitian ini Bagi pesantren, sebagai sarana untuk mengambil inisiatif dalam rangka penyempurnaan program pengembangan pesantren ke depan sehingga antara pesantren dan masyarakat sekitar dapat bekerjasama dalam pengembangan Pondok Pesantren. Bagi masyarakat, sebagai bahan masukan dalam mengambil inisiatif kebijaksanaan yang tepat dalam memberikan saran, kritik oleh pihak pesantren. Bagi fakultas Dakwah Dan Komunikasi, Jurusan Manajemen Dakwah.

Dengan adanya penelitian ini diharapkan dapat menghasilkan laporan penelitian yang bisa digunakan sebagai acuan atau pustaka bagi peneliti selanjutnya yang ingin mengkaji tentang peranan pemimpin dalam pengembangan Pondok Pesantren.Bagi penulis, sebagai bahan latihan dalam penulisan karya ilmiah, sekaligus sebagai tambahan informasi mengenai Pondok Pesantren dan eksistensinya dalam peranan seorang pemimpin.

Peneliti juga berharap semoga penelitian ini bisa turut memperkaya khazanah keilmuan sekaligus mendorong mahasiswa UIN untuk terus berkarya dalam upaya mengembangkan Manajemen Dakwah khususnya di Indonesia. Hasil penelitian ini diharapkan bermanfaat untuk menambah kekayaan khazanah Ilmu Dakwah, terutama dalam kajian Manajemen Dakwah.

Dalam penelitian ini, penulis menggunakan Metode yang digunakan dalam penelitian ini adalah penelitian kualitatif yaitu untuk mengetahui atau menggambarkan kenyataan dari kejadian yang diteliti sehingga memudahkan penulis untuk mendapatkan data yang objektif dalam rangka mengetahui dan memahami penelitian yang dikaji dan tipe penelitian yang digunakan dalam penelitian ini menggunakan metode deskriptif.

Sejalan dengan jenis data yang digunakan dalam penelitian ini adalah bersifat kualitatif deskriptif, maka proses analisis datanya akan ditempuh dengan cara mengolah, menganalisis, dan menafsirkannya secara kualitatif deskriptif terhadap kepemimpinan Ustadz Iwan Hermawan Dalam Mengembangkan Pondok Pesantren Salafiyah Al-Mu'awanah. Kp Lio Warung Gede. Desa Cibiru Wetan. 
Siti Muspiroh, A. Bachrun Rifa'i, \& Herman

Kecamatan Cileunyi. Kabupaten Bandung.

\section{LANDASAN TEORITIS}

Teori yang akan dijadikan landasan dalam penelitian ini adalah teori Kepemimpinan, dimana asal Kata "Kepemimpinan" terjemah dari bahasa inggris " leadership" banyak sekali kita temukan dalam kehidupan kita sehari-hari. Kata itu kita dengar dalam percakapan orang, dalam pertemuan-pertemuan, dari radio dan televise, kita dapat membaca dalam surat- surat kabar, majalah-majalah, bukubuku dan lain-lainnya. Seorang pemimpin adalah seorang yang dapat mengerak kan orang-orang lain disekitarnya (kelilingnya,bawahannya, dalam pengaruhnya) untuk mengikuti pemimpin itu.

Pemimpin dalam pengertian luas ialah seseorang yang memimpin, dengan jalan memprakarsai tingkah laku sosial dengan mengatur, mengarahkan, mengorganisir atau mengontor usaha/upaya orang lain atau melalui prestise, kekuasaan atau posisi. Dengan pengertian yang terbatas, pemimpin ialah seseorang yang membimbing, memimpin dengan bantuan kualitas persuasifnya dan akseptansi/penerimaan secara sukarela oleh para pengikutnya.

Dalam bukunya Pemimpin dan Kepemimpinan Kartini Kartono menjelaskan pengertian seorang pemimpin. Pemimpin adalah seorang pribadi yang memiliki superioritas tertentu, sehingga dia memiliki kewibawaan dan kekuasaan untuk menggerakan orang lain melakukan usaha bersama guna mencapai suatu tujuan tertentu.

Pemimpin dapat dikelompokkan menjadi pemimpin formal dan pemimpin informal. Pemimpin formal adalah seorang yang secara resmi diangkat dalam jabatan kepemimpinan, teratur dalam organisasi secara hirarkhi, apalagi dalam zaman pembangunan ini, tergambar dalam suatu gambar bagan yang tergantung dalam tiap-tiap kantor. Kepemimpinan formal ini lazimnya tidak dengan sendirinya dapat memberi jaminan bahwa seorang yang diangkat menjadi pemimpin formal dalam organisasi itu akan dapat diterima juga oleh anggota organisasi sebagai pimpinan yang sesungguhnya. Hal ini masih harus diuji dalam praktek. Pemimpin formal ini lazimnya dikenal dengan istilah "Kepala" (Zalukhu, 2017:8).

Pemimpin informal adalah kepemimpinan ini tidak mempunyai dasar pengangkatan resmi, tidak nyata terlihat dalam hirarkhi organisasi, juga tidak terlihat dalam gambar bagan. Pemimpin ini dengan spontan diterima baik oleh para anak buahnya, oleh karena pemimpin informal memancarkan daya atau sifatsifat kepemimpinan yang sungguh-sungguh. (Nawawi 2006:73-75).

Kepemimpinan efektif adalah puncak dari keberhasilan seseorang dalam menjalankan tugas kepemimpinan. Semua pemimpin menginginkan agar kepemimpinannya berjalan secara efektif. Namun demikian, untuk mencapai tingkat kepemimpinan efektif tidak semudah membalikkan telapak tangan. Pemimpin membutuhkan penguasaan beberapa faktor yang menyebabkan timbulnya efektivitas kepemimpinan ini. Sebagai konsekuensinya, perbincangan 
mengenai kepemimpinan efektif pada akhirnya akan memperbincangkan standar kepemimpinan yang ideal. Standar kepemimpinan yang hampir menjadi impian semua pemimpin. Itulah sebabnya, banyak perdebatan mengenai kepemimpinan yang efektif. Tulisan ini akan mencoba melakukan analisis tentang sifat-sifat kepemimpinan transformasional yang sejalan dengan model kepemimpinan dakwah sehingga dapat diaplikasikan dalam memimpin organisasi dakwah (Rahmat, 2012:12)

Teori Great Man dan Teori Big Bang, teori yang usianya sudah cukup tua ini menyatakan kepemimpinan merupakan bakat atau bawaan sejak seseorang lahir dari kedua orang tuanya. Teori Great Man (Orang Besar) berasumsi pemimpin dilahirkan bukan diciptakan. Teori ini melihat bahwa kekuasaan berada pada sejumlah orang tertentu, yang melalui proses pewarisan memiliki kemampuan memimpin atau karena keberuntungan memiliki bakat untuk menepeti posisi sebagai pemimpin. Dengan kata lain para pemimpin menurut teori ini berasal dari keturunan tertentu (di Indonesia disebut keturunan berdarah biru). Yang berhak menjadi pemimpin, sedang orang lain tidak ada pilihan selain menjadi pihak yang dipimpin.

Teori Sifat Atau Karakteristik Kepribadian (Trait Theories).Teori ini hampir sama dengan teori Great Man,meskipun berbeda dalam mengartikan bakat yang dimiliki seseorang pemimpin. Teori Great Man menekankan bakat dalam arti keturunan, bahwa seorang menjadi pemimpin karena memiliki kromosom (pembawa sifat) dari orang tuanya sebagai pemimpin. Dari pertemuan sel telur (ovum) di dalam Rahim seorang calon ibu dengan fspermatozoid seorang calon ayah terdapat gena-gena yang berisi kromosom (pembawa sifat) berupa bakat yang diwariskan pada seorang anak. Diantaranya terdapat bakat memimpin yang dominant. Contoh yang populer adalah seorang anak raja diasumsikan memiliki bakat ayahnya untuk menjadi raja sebagai seorang pemimpin.

Teori Perilaku (Behavior Theories). Teori ini bertolak dari pemikiran bahwa kepemimpinan untuk mengefektifkan organisasi. Tergantung pada perilaku atau gaya bersikap dan/atau gaya bertindak seorang pemimpin. Dengan demikian berarti juga teori ini memutuskan perhatiannya pada fungsi-fungsi kepemimpinan. Dengan kata lain keberhasilan seorang pemimpin dalam mengefektifkan organisasi, tergantung pada perilaku dalam melaksanakan fungsi-fungsi kepemimpinan di dalam strategi kepemimpinannya.

Jika disimpulkan dari pendapat para ahli, kepemimpinan adalah kemempuan memengaruhi orang lain, baik kelompok ataupun bawahan, kemampuan untuk mengarahkan sikap dan tindakan kelompoknya, mempunyai keahlian dan kemampuan khusus pada bidang-bidang tertentu yang dibutuhkan oleh kelompok guna mencapai tujuan kelompok. Adapun berbagai macam teori-teori kepemimpinan dalam buku kepemimpinan dan perilaku organisasi (Rivai,2012:710). 


\section{HASIL DAN PEMBAHASAN}

Berdasarkan penelitian yang telah dilakukan di Pondok Pesantren Salafiah AlMu'awanah bahwasanya Ustadz Iwan Hermawan memiliki tipe kepemimpinan, dimana beliau memiliki salah satu tipe kepemimpinan, salah satunya kepemimpinan demokratis dan karismatik. Dan pengambilan keputusan beliaupun tidak secara sepihak, meainkan memusyawarahkan terlebih dahulu kepada dewan santri, atau pengurus rois dan roisah sehingga mendapatkan kata mufakat dan memecahkan permasalahan yang sudah ada. Hubungan ustadz dan santri sudah seperti keluarga, ustadz selalu berbaur dan mengangap santri ikhwan seperti adik kandungnya sendiri, sehingga rasa nyaman itu hadir di lingkungan Pondok Pesantren Salafiyah Al-Mu'awanah, hal ini sesuai dengan hasil wawancara dari dewan santri yang menyebutkan bahwa:

\section{Tipe Kepemimpinan Ustadz Iwan Hermawan}

Ustadz Iwan Hermawan memiliki karisma yang mempengaruhi masyarakat dan santri sehingga mampu mengelola kegiatan yang ada di Pondok Pesanren, memiliki wibawa tersendiri yang membuat kami selalu tunduk dan patuh terhadapny.

Dengan kharisma yang dimilikinya, beliau mampu membangun Pondok Pesantren Al-Mu'awanah menjadi Pondok Pesantren yang unggul dalam ilmu, berkualitas dalam amal, tauladan dalam pergaulan yang sesuai dengan visi dari pesantren, dan selalu menjalankan syariat-syariat sesuai ajaran islam. Hal ini dapat dibuktikan semakin pesatnya perkembangan pondok pesantren Al-Mua'wanah.

Tipe kepemimpinan pada dasarnya mengandung pengertian sebagai suatu perwujudan tingkah laku dari seorang pemimpin yang menyangkut kemampuannya dalam memimpin suatu kelompok atau lembaga yang ada dalam suatu Pondok Pesantren. Salah satunya seperti di dalam lingkungan atau lembaga Pondok Pesantren Al-Mu'awanah, dimana sosok yang peneliti kenal sebagai pemimpin atau Ustadz yang berada di pondok pesantren, beliau memiliki ciri atau tipe kepemimpinan yang ada pada dirinya, sehingga lembaga atau yayasan yang ustadz dirikan dapat berkembang dan bisa mencapai sebuah Visi dan Misi dengan baik.

Jika disimpulkan dari pendapat para ahli, Tipe kepemimpinan adalah kemempuan memengaruhi orang lain, baik kelompok ataupun bawahan, kemampuan untuk mengarahkan sikap dan tindakan kelompoknya, mempunyai keahlian dan kemampuan khusus pada bidang-bidang tertentu yang dibutuhkan oleh kelompok guna mencapai tujuan kelompok. Adapun berbagai macam teoriteori kepemimpinan dalam buku kepemimpinan dan perilaku organisasi yang dikutip oleh (Veithzal Rivai 2012:7-10)

Dengan demikian, dapat dianalisis bahwa Ustadz Iwan Hermawan senantiasa memiliki tipe kepemimpinan Karismatik dan demokratis.

Ustadz selalu berharap dengan pembagian kerja yang sesuai dan dapat diterima dengan baik mudah-mudahan menjadi wujud akhlak santri, karena 
pada dasarnya santri itu memahami bahwa apapun yang mereka terima dari suatu amanah yang wajib dilaksanakan, dan tidak dilihat dari ruang lingkup apapun, baik sebuah amanah dalam ruang lingkup mengembangkan suatu intansi yang berjalan dalam menegakkan syiar islam dan dalam mencetak generasi-generasi yang akan datang yang insya Allah ada dalam kekuatan akidah dan istiqomah dalam ibadah kemudian berakhlakul karimah (wawancara dengan Rois Al-Mu'awanah)

Menurut hasil observasi yang dilkukan oleh penulis, tipe kepemimpinan Ustadz Iwan Hermawan memiliki perbedaan dan keunikan tersendiri. Hal ini terlihat dari gaya kepemimpinan Ustadz Iwan Hermawan yang memiliki tipe kepemimpinan campuran anatara gaya pimpinan karismatik dan demokratis. Gaya kepemimpinan karismatik terlihat karena kepribadiannya, dimana kepribadian tersebut dapat menunjukkan atau membedakan antara individu yang satu dengan individu yang lain.

Dengan kepribadiannya beliau mempunyai sifat-sifat yang khas yang membuat beliau dihormati, disegani, ditaati,dan dipatuhi baik di lingkungan pesantren maupun diluar lingkungan Pondok Pesantren. Hal ini dapat dibuktikan dari cara beliau mengajar dengan ciri khas yang berbeda, beliau selalu memposisikan dirinya sama dengan santri, tidak ada senioritas, tidak ada jenioritas melainkan beliau selalu menganggap santri belajar bersama-sama dalam jalan menuntut ilmu.

Sedangkan dalam melaksanakan tugasnya beliau mau menerima bahkan mengharapkan pendapat-pendapat dan saran-saran dari para santri, Ustadz selalu menerima masukan dan pendapat apabila ada kekurangan dalam sebuah kepemimpinan yang beliau laksanakan, serta tidak memandang bawahan dan atasan, ini menggambarkan bahwa beliau bersikap demokratis. Sehingga apa yang beliau katakan dan perintahkan jika memang itu yang terbaik untuk para santri, maka santripun melaksanakan dan mematuhi perintahnya, beliau sering membuka kesempatan bagi para santri khususnya santri ikhwan untuk bercerita atau meminta pendapat tentang permasalahan yang dihadapi nya, dan beliau selalu memposisikan dirinya sebagai seorang kaka yang mengayomi seorang adik, sehingga para santri ikhwan sangat nyaman di saat menceritakan atau konsul permasalahan yang dihadapi.

Pembagian wewenang di Pondok Pesantren Al-Mu'awanah terdapat Pembagian wewenang dengan membentuk adanaya organisasi, agar pembagian wewenang tersebut dapat terstruktur dengan baik. Hal tersebut sesuai dengan ungkapan Ustadz Iwan Hermawan:

Dalam kaidah menyatakan al-Haqqu billannidzhom sayuglabu bilbatili ma'annidzhom. Al-haq jika tidak disertai annidzhom adanya koordinasi yang baik adanya organisasi yang handal, maka akan cepat dan mudah di porak porandakan oleh al-batil yang ketika al-batil itu terorganisir dengan baik, maka harus adanya pembagian wewenang secara terstruktur (wawancara dengan Ustadz Iwan Hermawan 20 maret 2018). 
Sistem pertanggung jawaban yang ada di Pondok Pesantren Al-Mu'awanah di antaranya:

Pertama, lingkungan eksternal pesantren dan masyarakat penanggung jawabnya adalah pimpinan, jika terdapat permasalahan dalam lingkungan eksternal pesantren, maka pimpinan yang bertanggung jawab menghadapi permasalahan tersebut.

Kedua, Lingkungan internal pesantren, yang bertanggung jawab adalah pengasuh Pondok Pesantren yaitu Ustadz Iwan Hermawan dan Ustadzh Eni Nuraini di Pondok Pesantren, jika terdapat permasalahan dalam lingkungan Internal pesantren, maka pengasuh yang bertanggung jawab dalam menghadapi permasalahan tersebut.

Ketiga, adapun dalam praktik di lapangan dengan santri, yang bertanggung jawab adalah Pengurus dan dewan santri, jika terdapat permasalahan dalam lapangan yang berkaitan dengan santri di Pondok Pesantren, maka dewan santri menagani permasalahan tersebut, jika permasalahan tidak bisa ditangani oleh dewan santri maka akan diserahkan langsung ke pengasuh Pondok Pesantren.

Sistem pembagian kerja di Pondok Pesantren di atur sesuai job descpition masing-masing. Dalam struktur kepengurusan. Dalam menentukan kepengurusan ditentukan dengan memilih dan menetapkan santri yang memiliki potensi dalam bidang tersebut, selain itu diadakan juga pemilihan umum santri yang dilaksanakan secara demokrasi untuk memilih dan menetapkan rois, roisah, sekretaris, dan bendahara Organisasi Santri (OSAMU) di Pondok Pesantren Al-Mu'awanah, sebagaimana yang diterangkan oleh Ustadz Iwan Hermawan:

Dalam sistem pembagian kerja dibuat adanya pembagian bidang dalam organisasi santri Al-Mu'awanah yang lengkap dengan Job descptionnyamasing-masing, rois,roisah,sekretaris,bendahara,bidang pendidikan, bidang rohis, bidang kodeetik, bidang humas, bidang seni islam, bidang kesehatan, serta bidang sarana prasarana (wawancara dengan Ustadz Iwan Hermawan 20 maret 2018)

Sikap santri dalam menerima pembagian kerja , dari hasil wawancara dengan pengurus yang terlibat dalam pembagian kerja, serta menurut pandangan salah satu dewan mengatakan bahwa, selama ini dilihat dari umumnya sikap santri menerima apa yang menjadi tugasnya, dan kelihatan ada wujud tugasnya meskipun didalam pekerjaan nya ada yang giat, ada yang biasa-biasa saja, ada juga yang lalai, tetapi yang jelas setiap bidangnya terlihat ada geraknya, karena selalu ada evaluasi dalam setiap usaha, ketika ada pengajian yang kurang berjalan dari bidang pendidikan atau ada hal yang rusak dari sarana prasarana, ketika ada permasalahan dengan perpulangan masuk kedalam job kodeetik, semuanya terlihat ada hasil, itu menunjukan bahwa santri bersifat kompratif santri bersifat aktif dan senantiasa bertanggung jawab atas pembagian tugas itu sendiri.

Pemimpin selalu berharap dengan pembagian kerja yang sesuai dan dapat diterima dengan baik mudah-mudahan menjadi wujud akhlak santri, karena pada dasarnya santri itu memahami bahwa apapun yang mereka terima dari suatu 
amanah yang wajib dilaksanakan, dan tidak dilihat dari ruang lingkup apapun, baik sebuah amanah dalam ruang lingkup mengembangkan suatu intansi yang berjalan dalam menegakkan syiar islam dan dalam mencetak generasi-generasi yang akan datang yang insya Allah ada dalam kekuatan akidah dan istiqomah dalam ibadah kemudian berakhlakul karimah.

Menurut hasil observasi yang dilkukan oleh penulis, tipe kepemimpinan Ustadz Iwan Hermawan memiliki perbedaan dan keunikan tersendiri. Hal ini terlihat dari gaya kepemimpinan Ustadz Iwan Hermawan yang memiliki tipe kepemimpinan campuran anatara gaya pimpinan karismatik dan demokratis. Gaya kepemimpinan karismatik terlihat karena kepribadiannya, dimana kepribadian tersebut dapat menunjukkan atau membedakan antara individu yang satu dengan individu yang lain.

Dengan kepribadiannya beliau mempunyai sifat-sifat yang khas yang membuat beliau dihormati, disegani, ditaati,dan dipatuhi baik di lingkungan pesantren maupun diluar lingkungan Pondok Pesantren. Hal ini dapat dibuktikan dari cara beliau mengajar dengan ciri khas yang berbeda, beliau selalu memposisikan dirinya sama dengan santri, tidak ada senioritas, tidak ada jenioritas melainkan beliau selalu menganggap santri belajar bersama-sama dalam jalan menuntut ilmu.

Sedangkan dalam melaksanakan tugasnya beliau mau menerima bahkan mengharapkan pendapat-pendapat dan saran-saran dari para santri, Ustadz selalu menerima masukan dan pendapat apabila ada kekurangan dalam sebuah kepemimpinan yang beliau laksanakan, serta tidak memandang bawahan dan atasan, ini menggambarkan bahwa beliau bersikap demokratis. Sehingga apa yang beliau katakan dan perintahkan jika memang itu yang terbaik untuk para santri, maka santripun melaksanakan dan mematuhi perintahnya, beliau sering membuka kesempatan bagi para santri khususnya santri ikhwan untuk bercerita atau meminta pendapat tentang permasalahan yang dihadapi nya, dan beliau selalu memposisikan dirinya sebagai seorang kaka yang mengayomi seorang adik, sehingga para santri ikhwan sangat nyaman di saat menceritakan atau konsul permasalahan yang dihadapi.

\section{Pengambilan Keputusan Ustadz Iwan Hermawan}

Dalam sebuah organisasi, didalamnya terdapat seorang pemimpin yang menduduki suatu jabatan tertinggi dalam suatu lembaga tersebut ialah harus adanya keberanian untuk melakukan suatu pengambilan keputusan dalam suatu permasalahan. Adapun dalam kepemiminan yang dilakukan oleh Ustadz Iwan Hermawan memiliki cara pengambilan keputusan dengan musyawarah untuk mendapatkan hasil mufakat serta tercapainya suatu tujuan, agar suatu organisasi dapat berjalan dengan lancar apabila seorang pemimpin langsung cepet, tepat, praktis dan rasional serta memikul tanggung jawab yang sudah menjadi kewajibannya. Hal ini juga senada dengan hasil wawancara yang dilakukan oleh penulis kepada Rois Am yang mengatakan bahwa:

Ketika ada permasalahan di Pondok Pesantren beliau tidak langsung 
mengambil sikap secara sendiri namun beliau membicarakan terlebih dahulu kepada pengurus, dewan dan pihak yang bersangkutan, secara halus mengasih keringanan agar tidak mengulanginya lagi, dan apabila pihak tersebut mengulangi kesalahan yang kedua kalinya maka Ustadz akan mengasih sanksi dan bahkan dikeluarkan dari Pondok

Pesantren.(wawancara dengan Dewan Santri Muhammad Nasirudin 29 maret 2018).

Pesantren Salafiyah Al-Mu'awanah merupakan suatu lembaga yang bergerak dalam agama islam, maka tidak heran jika dalam suatu pengambilan keputusan memiliki kesamaan dalam lembaga-lembaga lainnya. Proses pengambilan keputusan dalam hal ini diartikan sebagai salah satu bagian dari rangkaian proses yang mesti dilalui oleh suatu lembaga, hal ini dilakukan untuk mempertahankan perkembangan dan ekisistensinya sehingga terwujud sebuah lembaga yang benarbenar dirasakan manfaatnya.

Pengambilan keputusan dalam menghadapi suatu permasalahan yang ada di Pondok Pesantren Al-Mu'awanah, dihadapi oleh Ustadz Iwan Hermawan dengan sangat rasional dan tidak mengutamakan emosi, secara bijak dan dengan mengumpulkan fakta-fakta yang ada dilapangan dalam hal ini kondisi anggota (santri dan pengurus). Walaupun beliau menyertakan pertimbangan pribadinya tidak menjadi masalah karena bukan semata-mata untuk kepentingan pribadinya, akan tetapi untuk kemajuan Pondok Pesantren.

Mengambil keputusan menjadi tindakan yang efektif (Malayu Hasibuan, 2011:61). Dalam penetapan sebuah keputusan beliau senantiasa memperhatikan kepentingan-kepentingan bersama yang memang secara umum diarahkan untuk kepentingan pondok pesantren dan pengembangannya, jadi dengan berbagai pertimbangan, keputusan pun dapat ditetapkan secara bijak.

Pemimpin model ini biasanya mengutamakan kerjasama, ini terlihat ketika ada kasus santri yang bertengkar, ghasob, dan melanggar peraturan kode etik. Ustadz Iwan tidak langsung mengambil sikap secara sendiri namun beliau membicarakan terlebih dahulu kepada pihak yang bersangkutan, secara halus mengasih keringanan agar tidak mengulanginya lagi, dan apabila pihak tersebut mengulangi kesalahan yang kedua kalinya maka Ustadz akan mengasih sanksi dan bahkan di keluarkan dari Pondok Pesantren.

Dalam tradisi Pesantren, gelar Ustadz biasanya digunakan untuk menunjukan para ulama dari kelompok islam tradisional, dan merupakan elemen paling pokok dalam sebuah Pondok Pesantren. Hubungan antara Ustadz dan santri dalam kehidupan sehari-hari, nampaknya sangat dipengaruhi oleh pandangan dan keyakinan yang hidup dikalangan para santri, bahwa Ustadz sebagai penyalur keilmuan yang dapat memancarkan kepada para santrinya. Selain itu, konsep-konsep ajaran islam yang mewajibkan seorang yang muda menghormati orang yang lebih tua, atau seorang anak harus hormat, patuh dan taat kepada orang tua, nampaknya sangat mempengaruhi bentuk pola hubungan diantara mereka. 
Ustadz, tidak hanya terbatas pada hubungan antara murid dengan gurunya, melainkan juga mencerminkan hubungan antara kaka dengan adiknya, dikarenakan Ustadz Iwan masih dibilang usianya tidak terlalu tua. Hal yang demikian, diakui pula oleh para santri di Pondok Pesantren Al-Mu'awanah, para santri menganggap Ustadz Iwan Hermawan seperti kaka sendiri, karna dari beliau sendirilah yang bisa memposisikan dimana beliau sedang formal dan informal (wawancara dengan Ustadz Iwan Hermawan 20 maret 2018)

Pemecahan masalah yang Ustadz lakukan dalam mengambil keputusan, alam peroses pengambilan keputusan biasanya melakukan kebijakan dalam menghadapi suatu permasalahan, yang pertama dengan cara menelusuri dengan seksama tentang subtansi dari masalah itu sendiri, terkadang ada masalah yang muncul tapi tidak komprehensif dalam berita yang sampai kepihak ustadz hingga yang pertama tama di lakukan tabayun terlebih dahulu sehingga lebih jelas permasalahan yang dihadapinya.

Kemudian jika berkaitan dengan santri, maka pertama-tama yang dilakukan adalah menanyakan keteman terdekatnya atau teman-teman sekamarnya, lalu di panggil santri yang bermasalah tersebut kemudian di ajak bicara, dan diikuti apa yang menjadi pokok permasalahan yang dihadapinya, kemudian setelah itu baru bisa di ambil suatu keputusan dari permasalahan yang terjadi, jika ruang lingkupnya dengan santri yang banyak tentunya dilakukan lebih seksama lagi dan melibatkan juga dewan santri dan tentunya musyawarah kepada Ustadz Iwan Hermawan.

Sebuah kebijakan lembaga atau yayasan Pondok Pesantren tersebut dan dilaksanakan dalam program-program yang tersusun secara sistematis yang akan dilaksanakan secara bersama-sama sesuai dengan job description (deskripsi pekerjaan) masing-masing pengurus. Beliau tidak mengambil suara terbanyak akan tetapi mengambil suara yang paling maslahat/terbaik. Musyawarah yang beliau tujukan untuk saling bertukar pendapat dan pemikiran. Jika musyawarah berjalan dengan baik, maka para pengurus termotivasi karena merasa dilibatkan dalam pengambilan keputusan yang berkaitan dengan kepengurusan atau yayasan. hasil wawancara yang dilakukan oleh penulis kepada Rois Am yang mengatakan bahwa:

Permasalahan yang ada di lingkungan pondok pesantren salah satunya seperti adanya santri yang melanggar peraturan yang memang sangat tidak baik jika berada di pondok pesantren, seperti jalan tidak dengan mahramnya, atau seringnya komunikasi yang berlebihan dengan lawan jenis (wawancara dengan Rois Al-Mu'awanah Leo Saputra 20 maret 2018)

Pandangan di pondok ini sangat tidak baik dan itu dinamakan salah satu permasalahan yang ada di pondok pesantren, beliau menyerahkan terhadap pengurus agar di tegur dan di kasih peringatan pertama, agar tidak mengulangi untuk yang kedua kalinya. Jika sudah diperingati dan di kasih teguran oleh pegurus namun masih melakukan kesalahan, ustadz iwan yang akan langsung turun tangan menangani dan mengambil kebijakan yang rasional terhadap keputusannya.

Di Pesantren Al-Mu'awanah musyawarah yang dilakukan dalam rangka memecahkan permasalahan dan menetapkan kebijakan program yang sudah ada, 
biasanya dilakukan rapat kepengurusan Osamu (Organisasi Santri Al-Mu'awanah) satu bulan sekali, dengan dihadiri oleh semua pengurus dan santri wan santri wati.

Berdasarkan pemaparan salah satu pengurus ternyata Pondok Pesanren AlMu'awanah memiliki kegiatan tahunan yang sering dilakukan oleh santri, diantaranya:

Program awal tahun ini terdiri dari penerimaan santri baru, setelah beberapa minggu menetap di pondok pesantren di adakannya masa ta'aruf santri baru (MOS), dan yang terakhir khusus ditahun sekarang karena awal pembelajaran itu dimulai pada bulan ramadhan, dan di pondok ini mengadakan kegiatan rutinan seperti tahun-tahun kemarin. Mengadakan pesantren kilat khusus anak diniyah yang berada dilingkungan pondok, dan juga mengadakan perlombaan-perlombaan antar pesantren, dan buka bersama dengan ustadz ustadzh di akhir ramadhan.

Program pertengahan ini terdiri dari mengadakan acara-acara islami seperti isra'mi'raj maulid nabi dan Al-mu'awanah, yang didalamnya terdapat santunan anak yatim dan duafa, dan perlombaan-perlombaan kreasi seni santri. Program unggulan biasanya Ziyaroh yang diadakan 1 tahun sekali setelah lebaran, meskipun program ini baru berjalan 5 tahun kebelakang, tapi di hadapan para santri program ini sangat dinanti-nanti, selain berziyarah keliling pulau jawa, santri pun bisa mengenal dan mendapat pelajaran dari berziyaroh tersebut (Wawancara Ustadz Iwan Hermawan).

Perkembangan masalah setelah adanya keputusan, Suatu lembaga atau yayasan yang sudah berkembang, dibalik semua itu adanya suatu proses yang hingga saat ini menghasilkan suatu perubahan menjadi lebih baik, adanya suatu permasalahan dan juga suatu kebijakan untuk memecahkan kendala-kendala yang dihadapi, dan yang sudah-sudah di Pondok Pesantren Al-Mu'awanah setelah adanya masalah kemudian dideteksi subtansi masalahnya lalu dipecahkan seksama dengan pengurus dan pihak yang bersangkutan dan setelah dilihat, perkembangannya mulai membaik. Meskipun hasilnya terkadang tidak bersipat langsung, adanya proses dan tidak instan. Ataupun ada juga yang instan perubahan tersebut tetapi tidak lama di tegaskan lagi dan baru dapat berjalan dengan baik.

Perkembangan masalah setelah adanya keputusan menjadi lebih baik dan tertata dengan rapih, karena setelah adanya kebijakan yang di putuskan oleh Ustadz Iwan Hermawan, santripun enggan dan tidak berani jika harus mengulangi kesalahan untuk yang kedua kalinya ataupun bagi para santri baru sudah tidak berani untuk melakukan kesalahan, karena di awal penerimaan santri baru sudah di informasikan bahwasannya peraturanperaturan dan larangan-larangan yang ada dipondok pesantren harus dilakukan dan ditaati tanpa terkecuali (Wawancara Ustadz Iwan Hermawan pada tanggal 20 Februari 2018).

Peran Ustadz Iwan Hermawan dalam Pengambilan Keputusan, Didalam suatu permasalahan ada yang sifatnya biasa dan juga ada yang tidak biasa, tergantung permasalahan yang dihadapi ada dimana, jika permasalahan yang dihadapi masih bisa dikendalikan oleh pengurus dan dewan santri, maka pengurus 
dan dewan santri saja yang bergerak untuk menyelesaikan permasalahan tersebut, karena disini santri tidak ingin memberatkan atau tidak ingin memberi beban lebih terhadap pimpinan, akan tetapi jika permasalahan bisa dibilang Ustadz harus mengetahuinya karena menyangkut suatu keputusan, maka pengurus akan langsung menyampaikan permasalahan yang dihadapi oleh santri kepada pengasuh .

Apabila permasalahan atau kendala berada di santri Wati Akhwat, maka Ustadz tidak terjun langsung, melainkan Istri dari Ustadz yang langsung menanganinya. Akan tetapi Ustadzh terlebih dahulu mendiskusikan apa permasalahan yang dihadapi dan bagaimana solusinya terhadap Ustadz. Contohnya seperti adanya ketidak harmonisan dalam kepengurusan santri akhwat. Ustadzh langsung mendiskusikan terhadap pengurus, mempertanyakan bagaimana dan apa kendalanya, lalu mempersilahkan santri Akhwat agar berpendapat, dan di jadikan satu suara kesepakatan pemecahan masalah, setelah itu Ustadzah langsung memberikan informasi hasil pemecahan masalah kepada Ustadz Iwan Hermawan, agar beliau mengetahui permasalahan dan pemecahan yang di hadapi santri Akwat, lalu Ustadz Iwan yang langsung mengambil keputusan hasil dari musyawarah dewan, ustadzh pengurus, dan langsung menetapkan keputusan yang rasional dan bijak.

Ustadz Iwan Hermawan tidak pernah ikut dalam diskusi ataupun rapat mingguan yang diadakan oleh pengurus Osamu (Organisasi Santri Al-Mu'awanah) akan tetapi beliau selalu memberikan masukan dan saran ataupun pendapat di luar forum rapat mingguan, beliau hanya menyampaikan lewat pengurus yang bersangkutan dan melalui pengurus tersebut akan disampaikan perkataanperkataan atau amanah dari Ustadz Iwan Hermawan.

Begitupun sebaliknya, para santri dengan tanggung jawabnya masing-masing disaat memiliki kendala ataupun keluhan beliau menanyakan kepada pengurus, dan pengurus langsung mempertanyakan kepada Ustadz agar permasalahan program yang dihadapi dapat terselesaikan. Ustadz Iwan Hermawan selalu terjun dan ada di saat pengambilan keputusan, karna seorang pengurus tidak akan berjalan jika tidak danya yang membimbing suatu organisasi tersebut (Wawancara Ustadz Iwan Hermawan pada tanggal 20 Februari 2018).

Uraian diatas memperlihatkan bahwa Ustadz Iwan Hermawan tidak mempergunakan wewenangnya sebagai pemimpin secara sewenang-wenang, akan tetapi ia mempengaruhi orang lain tidak disertai dengan paksaan sehingga bawahan dengan kesadarannya sendiri melaksanakan tugas sesuai dengan job description (pembagian tugas) yang dimilikinya.

Dengan demikian, dapat dianalisis dari teori James A. F. Stoner bahwa dalam pelaksanaan pengambilan keputusan Ustadz Iwan Hermawan senantiasa melakukan analisis yang matang secara musyawarah dan tanggungjawab atas pengambilan keputusan yang dilakukan.

\section{Interaksi Ustadz dengan santri.}


Pemimpin yang memiliki tipe karismatik dan demokratis, memiliki wibawa dan ilmu yang dikuasainya, diiringi dengan tingkah laku dan sifat yang baik patut di contoh dengan santri yang berada di lingkungan Pondok Pesantren. interaksi yang dilakukan oleh ustadz penuh dengan santun, perkataan yang terucap selalu mengandung makna, tidak ada hal yang begitu bisa di nilai tidak etis, seperti memanggil identitas santri tidak dengan nama, melainkan memanggil dengan panggilan yang sopan, seperti akang, teteh, aa, abang, Ustadz menganggap semuanya santri sama, tidak adanya senioritas ataupun jenioritas, dan di terapkan dalam keseharian, menyaba atau saling memanggil dengan sebutan akang dan teteh tanpa mengenal batas usia.

Hubungan interaksi Ustadz dengan santri tidak hanya melalui satu atau dua definisi saja. Hal itu tidaklah mudah, karena berbagai definisi memiliki redaksi yang berbeda tetapi pada prinsipnya memiliki pengertian yang sama. Pengertian Human Relations sangat beragam. Human Relations adalah keseluruhan rangkaian hubungan, baik yang bersifat formal atau informal. Antara atasan dengan bawahan, atasan dengan atasan, serta bawahan dengan bawahan yang lain harus dibina dan dipelihara dengan baik agar terciptanya suatu kerja sama "team-work" dan suasana kerja yang serasi dan harmonis dalam rangka pencapaian suatu tujuan (Sondang 2004:6)

Ustadz Iwan suka berdiskusi tidak formal setelah pengajian selesai dengan santri, membicarakan keluhan-keluhan yang di hadapi oleh santri, berbicara menyangkut keluhan santri yang sudah lulus kuliah dan belum mendapatkan jodoh. Senantiasa Ustadz berkomunikasi untuk mempererat hubungan dan talisilaturahmi, baik terhadap santri ataupun alumni yang sudah meninggalkan Pondok Pesantren.

Jika ada kegiatan atau kerja bakti pondok, Ustadz selalu ikut terjun langsung, walaupun mungkin disaat Ustadz memegang sapu atau alat lainnya, santripun langsung menggantikannya dan melanjutkan pekerjaan Ustadz tersebut. Interaksi Ustadz dengan santri sudah sangat baik, komunikasi yang terus berjalan dan bergotong royong untuk memajukan Pondok Pesantren.( Wawancara dengan para santri Ikhwan ).

Akan tetapi interaksi dengan santri akhwat sangat terbatasi, hanya berkomunikasi disaat pengajian berlangsung, bahkan butuh waktu agar Ustadz dapat menghafal santri Akhwat, karna kurangnya komunikasi antar Ustadz dan santri wati, semua ini karna ustadz menjaga batas-batas atau mengikuti syariat islam wanita yang bukan mahramnya sangat di larang untuk berlebihan berkomunikasi. Sebagaimana dijelaskan oleh Ustadz Iwan Hermawan:

Interaksi yang dilakukan dengan santri hanya dalam ruang lingkup pengajian, di luar pengajian (sama-sama ikhwan) jika akhwat sangat terbatas. Karna ada hukum yang berlaku (Wawancara Ustadz Iwan Hermawan pada tanggal 20 Februari 2018).

Ustadz Iwan Hermawan sangat berperan dalam pengembangan Pondok Pesantren baik secara langsung ataupun tidak langsung. Kepemimpinan Ustadz 
Iwan Hermawan sangatlah mempengaruhi perkembangan Pondok Pesantren AlMu'awanah sampai saat ini, dan hal itu terlihat dari meningkatnya sejumlah fasilitas dan banyak santri dari tahun ke tahun. Hal itu membuktikan terjadinya suatu peningkatan baik dari segi bangunan, fisik, santri yang meningkat, dan ini jelas pengaruh kepemimpinan yang ada dalam diri Ustadz Iwan Hermawan.

\section{PENUTUP}

Penelitian ini mendeskripsikan kepemimpinan Ustadz Iwan Hermawan dalam mengembangkan Pondok Pesantren Salafiyah Al-Mu'awanah. Kepemimpinan Ustadz Iwan Hermawan tersebut dapat disimpulkan sebagai berikut: Berdasarkan wawancara yang dilakukan langsung dengan Ustadz Iwan Hermawan beserta Pengurus Rois dan Roisah beserta jajarannya dan dengan santri-santri AlMu'awanah, kepemimpinan Ustadz Iwan Hermawan telah mencapai beberapa target yang telah di rencanakan dan ditentukan sebelumnya.

Pertama Tipe kepemimpinan Ustadz Iwan Hermawan ialah tipe demokratis dan kharismatik gaya kepemimpinan karismatik terlihat karena kepribadiannya, yang menunjukkan atau membedakan antara individu yang satu dengan individu yang lain. Dengan kepribadiannya beliau mempunyai sifat-sifat yang khas yang membuat beliau dihormati, disegani, ditaati,dan dipatuhi baik di lingkungan pesantren maupun diluar lingkungan pondok pesantren.

Demokratis ialah Ustadz dapat menempatkan dan memposisikan factor manusia sebagai paktor utama dan terpenting. Dalam kepemimpinan ini setiap individu sebagai manusia diakui, dihargai, dihormati dan kepemimpinannya dalam memajukan dan mengembangkan pondok pesantren.

Kedua, Pengambilan keputusan pemimpin dalam pelaksanaan pengambilan keputusan senantiasa menerapkan Prinsip Musyawarah dan kebersamaan untuk mencapai kata mufakat dengan semua orang yang bersangkutan. Beliau selalu mempertimbangkan serta memperhitungkan dengan baik kemudian meninjau dan mengevaluasi keputusan tersebut. Bahwa pengambilan keputusan Ustadz adalah Pembuatan keputusan rasional. Ialah pembuatan yang berdasarkan informasi yang objektif dan proses yang logis. Prosesnya konsisten dengan pola yang telah teruji, melakukan penilaian dan penghitungan alternatife-alternatif yang tersedia untuk mencapai pilihan yang maksimal dalam keterbatasan sumber-sumber dalam lingkungan

Ketiga, Hubugan persatuan dan kesatuan pemimpin dengan santri begitu melekat, kebersamaan yang begitu erat sehingga menghasilkan rasa nyaman. Ustadz selalu tawadu dan memposisikan dirinya kepada santri hanya sekedar santri yang sama-sama belajar untuk mencari ilmu, dan kebersamaan yang beliau ciptakan menghasilkan rasa kekeluargaan yang ada di Pondok Pesantren.

Sehubungan telah selesai penulisan Skripsi ini, ada beberapa rekomendasi yang bisa dilaksanakan oleh Pondok Pesantren Al-Mu'awanah, dan para penulis selanjutnya yang ingin meneliti tentang kepemimpinan.

Pertama, untuk Pondok Pesantren Pelaksanaan Program-program 
Siti Muspiroh, A. Bachrun Rifa'i, \& Herman

hendaknya dilaksanakan dengan penuh kesemangatan dan keikhlasan sehingga bisa dilaksanakan dengan lancar dan baik.

Kedua, untuk peneliti diharapkan harus memperbanyak pengumpulanpengumpulan data yang ada di Pondok Pesantren demi kelancaran dan kesempurnaan penelitian yang dilakukan.

Ketiga, untuk Pondok Pesantren yaitu dalam pembangunan, diharapkan santri untuk berpartisifasi dan bergotong royong terutama dalam peningkatan kualitas sumber daya alam.Dalam suatu kepengurusan, diharapkan kerjasama koordinasi dan saling membantu program-program yang ada di pondok, agar kepengurusan dapat berjalan dengan baik.

\section{DAFTAR PUSTAKA}

Aripudin, Acep. (2012). Pesantren dan Konflik Keluarga (Studi Kasus Pesantren Alfadiliyah Ciamis) dalam Ilmu Dakwah: Academic Journal for Homiletic Studies, Vol. 6

Allolangi, Yusuf Rahmat. (2012). Kepemimpinan Transformasional Sebagai Kepemimpinan Dakwah. Ilmu Dakwah: Academic Journal for Homiletic Studies, Vol.6 6(12) 151-169.

Hamzah,Yaqub. (1992). Publisistik, Teknik Dakwah dan Leadership. Jakarta: Diponegoro.

Haedari, H. Amin. 2007. Transformasi Peasntren. Jakarta: Media Nusantara.

Hadari Nawawi \& Martin Hadari. 2006. Kepemimpinan yang Efektif. Yogyakarta: Gajah Mada University Press.

Karjadi. (1989). Kepemimpinan (Leadership). Bogor: PT.Karya Nusantara Bandung.

Mujamil, Qomar. 2002. Pesantren dari Transformasi Metodologi Menuju Demokrasi Institusi,. Jakarta: Erlangga.

Madjid, Nurcholish. (1997). Bilik-Bilik Pesantren, Sebuah Potret Perjalanan. Jakarta: Paramadina.

Nawawi, H. Hadari. (2003). Kepemimpinan mengefektifkan organisasi. Gadjah Mada University Press.

Sadiah, Dewi. (2015). Metode Penelitian Dakwah. Bandung: PT. Remaja Rosdakarya

Zalukhu, Eloy. (2017). I'm A Leader. Jakarta: P'. Gramedia 